\title{
Quantification of the impact of climate uncertainty on regional air quality
}

\author{
K.-J. Liao ${ }^{1}$, E. Tagaris ${ }^{1}$, K. Manomaiphiboon ${ }^{1,4}$, C. Wang ${ }^{2}$, J.-H. Woo ${ }^{3,5}$, P. Amar ${ }^{3}$, S. He ${ }^{3}$, and A. G. Russell ${ }^{1}$ \\ ${ }^{1}$ School of Civil and Environmental Engineering, Georgia Institute of Technology, Atlanta, GA, USA \\ ${ }^{2}$ Joint Program on the Science and Policy of Global Change, Massachusetts Institute of Technology, Boston, MA, USA \\ ${ }^{3}$ Northeast States for Coordinated Air Use Management (NESCAUM), Boston, MA, USA \\ ${ }^{4}$ Joint Graduate School of Energy and Environment, King Mongkut's University of Technology Thonburi, Bangkok, Thailand \\ ${ }^{5}$ Department of Advanced Technology Fusion, Konkuk University, Seoul, Korea
}

Received: 18 January 2008 - Published in Atmos. Chem. Phys. Discuss.: 21 April 2008

Revised: 17 December 2008 - Accepted: 2 January 2009 - Published: 3 February 2009

\begin{abstract}
Uncertainties in calculated impacts of climate forecasts on future regional air quality are investigated using downscaled MM5 meteorological fields from the NASA GISS and MIT IGSM global models and the CMAQ model in 2050 in the continental US. Differences between three future scenarios: high-extreme, low-extreme and base case, are used for quantifying effects of climate uncertainty on regional air quality. GISS, with the IPCC A1B scenario, is used for the base case simulations. IGSM results, in the form of probabilistic distributions, are used to perturb the base case climate to provide the high- and low-extreme scenarios. Impacts of the extreme climate scenarios on concentrations of summertime fourth-highest daily maximum 8-h average ozone are predicted to be up to $10 \mathrm{ppbV}$ (about one-seventh of the current US ozone standard of $75 \mathrm{ppbV}$ ) in urban areas of the Northeast, Midwest and Texas due to impacts of meteorological changes, especially temperature and humidity, on the photochemistry of tropospheric ozone formation and increases in biogenic VOC emissions, though the differences in average peak ozone concentrations are about $1-2 \mathrm{ppbV}$ on a regional basis. Differences between the extreme and base scenarios in annualized $\mathrm{PM}_{2.5}$ levels are very location dependent and predicted to range between -1.0 and $+1.5 \mu \mathrm{g} \mathrm{m}^{-3}$. Future annualized $\mathrm{PM}_{2.5}$ is less sensitive to the extreme climate scenarios than summertime peak ozone since precipitation scavenging is only slightly affected by the extreme climate scenarios examined. Relative abundances of biogenic VOC and anthropogenic $\mathrm{NO}_{\mathrm{x}}$ lead to the areas that are most responsive to climate change. Overall, planned controls for decreasing regional ozone and $\mathrm{PM}_{2.5}$ levels will continue to
\end{abstract}

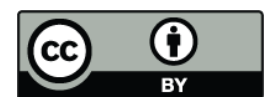

Correspondence to: A. G. Russell (ted.russell@ce.gatech.edu) be effective in the future under the extreme climate scenarios. However, the impact of climate uncertainties may be substantial in some urban areas and should be included in assessing future regional air quality and emission control requirements.

\section{Introduction}

Impacts of future climate change on regional air quality have been investigated for different regions, years and emission scenarios. Due to uncertainties inherent in climate forecasts, the Intergovernmental Panel on Climate Change (IPCC) investigated multiple scenarios associated with different projections of future anthropogenic emissions of greenhouse gases (GHGs) as part of IPCC's Special Report on Emissions Scenarios (SRES) (IPCC, 2007; Nakićenović, 2000). Hogrefe et al. (2004) predict an increase in spatially averaged summertime daily maximum 8-h $\mathrm{O}_{3}$ concentrations of $4.2 \mathrm{ppbV}$ in the 2050s over the eastern US based on the IPCC A2 scenario and assuming anthropogenic precursor emissions and boundary conditions to remain constant. Murazaki and Hess (2006) suggest an increase of up to 12 additional days in the northeast of the continental US each year exceeding daily maximum 8 -h average ozone concentrations of $80 \mathrm{ppbV}$ in the decade 2090s compared with 1990s, assuming that future precursor emissions remain at 1990 levels and GHG emissions follow A1 scenario. Racherla and Adams (2006) predict an increase up to $5 \mathrm{ppbV}$ in ozone concentrations over the eastern US while the global burdens and the lifetimes of all the fine particulate matter species decreased by 2 to $18 \%$ between 1900s and 2050s assuming climate will follows the IPCC A2 scenario and anthropogenic

Published by Copernicus Publications on behalf of the European Geosciences Union. 
emissions remain constant. Sanderson et al. (2003) predict a $10-20 \mathrm{ppbV}$ increase in ozone concentrations during July due to a combined effect of changes in vegetation and prescribed IPCC IS92a CO 2 emissions in 2090s compared with 1990s over the majority of the US.

The objective of this study is to investigate how uncertainties inherent in climate change forecasts impact regional air quality predictions over the continental US using multiple climate futures. Given that model inputs (e.g., regional meteorology and precursor emissions) and parameterizations/assumptions lead to uncertainties in regional downscaling of future climate and air quality modeling (which have been presented elsewhere, e.g., Bergin et al., 1998; Russell and Dennis, 2000; Hanna et al., 2001; Hanna et al., 2005; Gustafson and Leung, 2007), the purpose of this study is not to specifically forecast future air quality but to quantify the impact of climate uncertainties on regional air quality forecasts, particularly focusing on ground-level ozone and $\mathrm{PM}_{2.5}$ (particulate matter with an aerodynamic diameter less than $2.5 \mu \mathrm{m}$ ) due to their adverse health-related effects (Bernard et al., 2001; Galizia and Kinney, 1999; Johnson and Graham, 2005). Of particular interest are the uncertainties associated with the "climate penalty" (increases in levels of air pollutants caused by climate change, Mickley et al., 2004) and investigating if uncertainties in climate predictions suggest alternative emission control strategies.

\section{Method}

2.1 Downscaling of global climate models to a meso-scale meteorological model

The meso-scale meteorological model, MM5 (The FifthGeneration NCAR/Penn State Mesoscale Model) (Grell et al., 1994; Seaman, 2000), is used to downscale outputs from the NASA Goddard Institute of Space Studies (GISS) global climate model (GCM) (Rind et al., 1999) to regional scale for studying effects of climate on regional air quality in year 2050. 2050 is chosen for this study as a compromise between non-trivial climate modification and a reasonable horizon for regional air quality planning. The GISS-MM5 climate fields, following the IPCC A1B scenario, are used as base case meteorological fields in this study. Details in GISS global climate simulation and downscaling of GISS global climate to meso-scale climate are described by Mickley et al. (2004) and Leung and Gustafson (2005), respectively. The IPCC A1B emission scenario assumes a future world of very rapid economic growth with a balanced case between fossil and non-fossil energy sources and projects mid-level increases in greenhouse gas emissions and temperatures (Nakićenović, 2000). As such, the IPCC A1B is used for the base case GISS-MM5 simulations within multiple IPCC scenarios. For assessing uncertainties in climate projections and their associated effects on regional air quality, it is useful to investi- gate uncertainties in individual, but covering, climate variables (e.g., temperature, absolute humidity, etc.) in terms of their probabilistic distributions instead of qualitative assessments. In this study, climate fields from MIT's Integrated Global System Model (IGSM) (Prinn et al., 1999; Reilly et al., 1999) simulations, in the form of probabilistic distributions, are used to quantify uncertainties inherent in forecasts of future changes, and their associated effects on regional air quality. The IGSM is composed of: (a) the Emissions Prediction and Policy Analysis (EPPA) model, designed to project emissions of climate-relevant gases and the economic consequences of policies to limit them (Babiker et al., 2000), (b) the climate model, a 2-D zonally-averaged land-ocean resolving atmospheric model, coupled to an atmospheric chemistry model, (c) a 2-D ocean model consisting of a surface mixed layer with specified meridional heat transport, diffusion of temperature anomalies into the deep ocean, an ocean carbon component, and a thermodynamic sea-ice model (Sokolov and Stone, 1998; Holian et al., 2001; Wang et al., 1998), (d) the Terrestrial Ecosystem Model (TEM 4.1) (Melillo et al., 1993; Tian et al., 1999), designed to simulate carbon and nitrogen dynamics of terrestrial ecosystems, and (e) the Natural Emissions Model (NEM) that calculates natural terrestrial fluxes of $\mathrm{CH}_{4}$ and $\mathrm{N}_{2} \mathrm{O}$ from soils and wetlands (Prinn et al., 1999). The probabilistic distributions of changes in climate fields in 2050 were derived from a set of 1000 ensemble simulations (Webster et al., 2003). In configuring this ensemble of simulations, the model uncertainty is included by using a joint PDF of three climate model parameters, i.e., climate sensitivity, ocean heat uptake, and aerosol radiative forcing along with PDF of predicted anthropogenic emissions of major greenhouse gases which is calculated using Monte Carlo analysis of the EPPA model. The IGSM provides 2-D longitudinally and monthly averaged meteorological fields. For uncertainty analyses, extreme cases from probabilistic distributions of climate fields are of interest for policy-making. The use of the 2-D model allowed development of wider probabilistic distributions from which a wide variety of proposed policies and extreme future cases can be chosen (Prinn et al., 1999).

Temperature and absolute humidity fields from the GISSMM5 climate are chosen for perturbations as they are strongly correlated with regional ozone and secondary $\mathrm{PM}_{2.5}$ levels (Sillman and Samson, 1995; Wunderli and Gehrig, 1991; Wise and Comrie, 2005; Strader et al., 1999; Seinfeld and Pandis, 2006; Nenes et al., 1998). Climate fields used are associated with the 0.5 th, 50 th and 99.5 th percentiles of temperature and absolute humidity from IGSM. The 50th percentile of both the meteorological parameters are adjusted to the GISS-MM5 by minimizing the discrepancies in temporal and spatial resolutions between the 50th IGSM and GISSMM5 outputs and used to develop perturbation fields along with the GISS-MM5 based on the following processes:

First, a three-dimensional time-dependent variable of the GISS-MM5 climate is decomposed into a spatially 
(longitudonally) and temporally (monthly) averaged field and a fluctuating term (Eq. 1).

$M(y, x, z, t)_{\mathrm{GISS}-\mathrm{MM} 5}=\overline{M(y, z, m)_{\mathrm{GISS}-\mathrm{MM} 5}}$

$+M^{\prime}(y, x, z, t)_{\mathrm{GISS}-\mathrm{MM} 5}$

where

$M(y, x, z, t)_{\mathrm{GISS}-\mathrm{MM} 5}$ : Original GISS-MM5 climate field (temperature and absolute humidity)

$\overline{M(y, z, m)_{\mathrm{GISS}-\mathrm{MM} 5}}$ : Longitudinally and monthly-average of $M(y, x, z, t)_{\mathrm{GISS}-\mathrm{MM} 5}$ ("steady term" of

$\left.M(y, x, z, t)_{\mathrm{GISS}-\mathrm{MM} 5}\right)$

$M^{\prime}(y, x, z, t)_{\mathrm{GISS}-\mathrm{MM} 5}$ : Fluctuating term of

$M(y, x, z, t)_{\mathrm{GISS}-\mathrm{MM} 5}$, where

$\sum_{t, x} M^{\prime}(y, x, z, t)_{\mathrm{GISS}-\mathrm{MM} 5}=0$

$y$ : latitude, $z$ : altitude, $x$ : longitude

$m$ : monthly-averaged values

$t$ : MM5 temporal resolution of every 6-h

Second, the longitudinally and monthly-averaged term, $\overline{M(y, z, m)_{\mathrm{GISS}-\mathrm{MM} 5}}, \quad$ is replaced with the 0.5 th, 50th and 99.5th percentiles of meteorological fields from the IGSM results (i.e., $\overline{M(y, z, m)_{0.5 \%}}$, $\overline{M(y, z, m)_{50 \%}}$ and $\overline{\left.M(y, z, m)_{99.5 \%}\right)}$ and used to construct intermediate three-dimensional climate fields (i.e., $M(y, x, z, t)_{\text {INT_0.5\% }}, M(y, x, z, t)_{\text {INT_50\% }}$ and $\left.M(y, x, z, t)_{\text {INT_99.5\% }}\right)$ along with the fluctuating term $\left(M^{\prime}(y, x, z, t)_{\mathrm{GISS}-\mathrm{MM} 5}\right)$ for the three percentiles separately (Eq. 2).

$M(y, x, z, t)_{\mathrm{INT} \_\mathrm{IGSM} \%}=\overline{M(y, z, m)_{\mathrm{IGSM}} \%}$

$+M^{\prime}(y, x, z, t)_{\mathrm{GISS}-\mathrm{MM} 5}$

where

$M(y, x, z, t)_{\text {INT_IGSM } \%: \quad \text { Intermediate three-dimensional }}$ climate field

$\overline{M(y, z, m)_{\mathrm{IGSM} \%}}:$ IGSM climate field

$M^{\prime}(y, x, z, t)_{\mathrm{GISS}-\mathrm{MM} 5}$ is defined in Eq. 1.

IGSM $\%: 0.5 \%, 50 \%$ and $99.5 \%$

Finally, the new three-dimensional time-dependent climate fields for each of the three percentiles (i.e., $M(y, x, z, t)_{0.5 \%}$, $M(y, x, z, t)_{50 \%}$ and $\left.M(y, x, z, t)_{99.5 \%}\right)$ are derived by

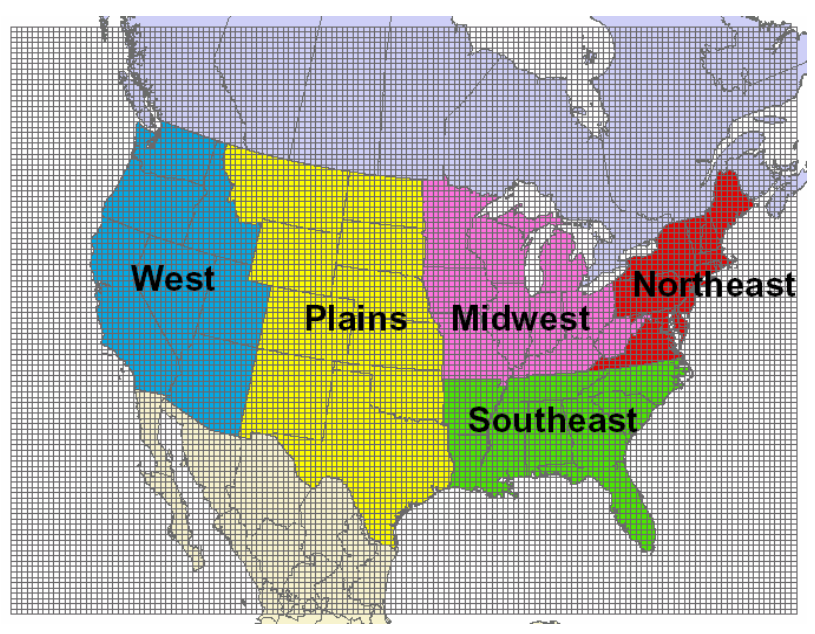

Fig. 1. Simulation domain and US regions.

re-running MM5 with new initial and boundary conditions (i.e., $M(y, x, z, t)_{\mathrm{INT} \_0.5 \%}, M(y, x, z, t)_{\mathrm{INT} \_50 \%}$ and $M(y, x, z, t)_{\text {INT_99.5\% }}$ from step 2$)$ in order to get conservative meteorological fields.

We keep the GISS-MM5 field ( $\left.M(y, x, z, t)_{\mathrm{GISS}-\mathrm{MM} 5}\right)$ as the base case scenario in order to compare with current pollutant levels (note that new fields of the IGSM 50th percentile climate are not identical to the GISS-MM5 fields). The highand low-extreme fields are calculated as follows (Eq. 3a and b):

High - extreme climate $=M(y, x, z, t)_{99.5 \%}$

$-M(y, x, z, t)_{50 \%}+M(y, x, z, t)_{\mathrm{IGSM}-\mathrm{MM} 5}$

Low - extreme climate $=M(y, x, z, t)_{0.5 \%}$

$-M(y, x, z, t)_{50 \%}+M(y, x, z, t)_{\mathrm{IGSM}-\mathrm{MM} 5}$

It is recognized that using MM5 for downscaling the temperature and absolute humidity distributions from the IGSM outputs may not capture the full range of uncertainty in climate change, however, the new fields do capture the extreme cases from the probabilistic distributions of both the meteorological fields, and the other meteorological fields (e.g., precipitation, wind fields, etc.) are dynamically consistent and responsive to the perturbations in temperature and absolute humidity.

\subsection{Emission and air quality modeling}

The simulation domain in this study covers the continental US as well as parts of Canada and Mexico. For more detailed analysis, the continental U.S is divided into five regions West, Plains, Midwest, Northeast and Southeast (Fig. 1). 
MM5 results are inputs to the Sparse Matrix Operating Kernel for Emissions (SMOKE) (http://www.smoke-model.org/ index.cfm, last access: 15 December 2008) for estimating emissions of precursors, and to the Community Multiscale Air Quality Model (CMAQ) version 4.3 (Byun and Schere, 2006) for simulating impacts of climate uncertainties on regional air quality in 2050. Details of the projections of future precursor emissions and regional air quality modeling approach are given elsewhere (Tagaris et al., 2007; Woo et al., 2008), and summarized here. The IPCC A1B emission scenario projects decreases in $\mathrm{SO}_{2}, \mathrm{NO}_{\mathrm{x}}$ and non-methane volatile organic compound (NMVOC) emissions from Organization for Economic Co-operation and Development (OECD) countries, including the US and Canada, in 2050s as compared with 1990s based on long-term energy-use and economic trends, which don't include currently planned precursor emission control regulations (Nakićenović, 2000). For future regional air quality modeling, projections in regional anthropogenic precursor emission changes are required in addition to national and global emission trends. In this study, projections of regional anthropogenic precursor emissions were developed for North America integrating currently planned emission controls (i.e., US Clean Air Interstate Rule (CAIR); Houyoux, 2004) and long-term economic and population growth, based on the A1B scenario. Although the same projected emission inventories are applied in the uncertainty simulations in 2050, simulated emissions of precursors of pollutants for the three climate scenarios are not identical since emissions (especially biogenic volatile organic compounds (VOCs)) respond to changes in meteorological fields (e.g., temperature, precipitation, etc.) (see Table S2 http://www.atmos-chem-phys.net/9/865/2009/ acp-9-865-2009-supplement.pdf).

The highest daily maximum 8-h average ozone (MDA8h $\mathrm{O}_{3}$ ) levels, which are often associated with adverse health effects in epidemiologic studies and used for assessing attainment of the US National Ambient Air Quality Standards (NAAQS) for ozone (Bernard et al., 2001; Levy et al., 2001), consistently occur in summer. Three summer months (June, July and August) in the year-2050 are chosen as the target period for studying the impact of climate uncertainties on the average and 4th highest MDA8h O ${ }_{3}$ (4th MDA8h $\mathrm{O}_{3}$ ) concentrations. The 4th highest value is chosen as being more stably predicted by chemical transport models than the maximum in any location. For $\mathrm{PM}_{2.5}$, one month from each of the four seasons (i.e., January, April, July and October) in 2050 is chosen for studying the impact of climate uncertainties on annualized $\mathrm{PM}_{2.5}$ levels because $\mathrm{PM}_{2.5}$ has distinct seasonal variation and an annual healthbased standard (http://www.epa.gov/air/criteria.html, last access: 15 December 2008). Interannual variability of meteorology is a critical issue since only the year 2050 is chosen as the future episode examined in this study. The analysis for the interannual variability of climate fields has been presented by Tagaris et al. (2007): the results show that cumula- tive distribution function (CDF) and spatial distribution plots for temperature and absolute humidity are similar for the three consecutive future years (2049-2051). The former paper provides information on interannual variability, and this paper looks at perturbations to the modeled base meteorology.

\section{Results and discussion}

\subsection{Meteorology}

The annualized temperatures (average temperatures of January, April, July and October) of the 2050 base GISS-MM5 climate, based on the IPCC A1B scenario, are predicted to be $0.4-2.4 \mathrm{~K}$ warmer than 2001 , depending on the region, whereas absolute humidity values are simulated to be approximately $0.5 \mathrm{~g} / \mathrm{Kg}(9 \%)-0.7 \mathrm{~g} / \mathrm{Kg}(14 \%)$ higher than 2001 (Table 1). Spatial distributions of annualized temperature and absolute humidity between the base case GISSMM5 and IGSM 50th percentile climate are found to be similar (Fig. S1 http://www.atmos-chem-phys.net/9/865/2009/ acp-9-865-2009-supplement.pdf), although regional average values differ slightly since the IGSM 50th percentile data has been used for re-running MM5 after being adjusted to the base case GISS-MM5 (Table 1). On the other hand, annualized temperatures and absolute humidity of the two 2050 extreme scenarios are predicted to change approximately from $-0.8 \mathrm{~K}$ (low-extreme) to $+2.1 \mathrm{~K}$ (high-extreme) and $-0.4 \mathrm{~g} / \mathrm{Kg}(-7 \%)$ (low-extreme) to $+1.1 \mathrm{~g} / \mathrm{Kg}(+19 \%)$ (high-extreme), respectively, as compared with the 2050 base scenario on a regional basis (Table 1). Summer (JJA) temperatures and absolute humidity values are predicted to be higher for the 2050 base case than 2001 climate (Table 1). Differences between the high-extreme and base case scenarios are found to be larger than differences between the lowextreme and base scenarios for both temperature and absolute humidity (Figs. 2 and 3). This reflects that the probability density functions of predicted temperatures and absolute humidity are not normally distributed but have a long right-hand tail in the IGSM outputs (Table S1) (Webster et al., 2003). Annualized precipitation is found to be somewhat different for the three scenarios in 2050 , with a $0.1 \mathrm{~mm} /$ day decrease in summer precipitation in the Plains for the highextreme scenario as compared with the base case (Fig. 4). The differences in precipitation between the 2050 base case and extreme scenarios are driven by the perturbations in temperatures and absolute humidity and based on the extreme percentiles of probabilistic distributions of temperature and absolute humidity changes derived from global modeling in 2050.

\subsection{Emissions}

Both sulfur dioxide $\left(\mathrm{SO}_{2}\right)$ and nitrogen oxides $\left(\mathrm{NO}_{\mathrm{x}}\right)$ emissions are forecast to be $51 \%$ lower for the 2050 base case 
(a)

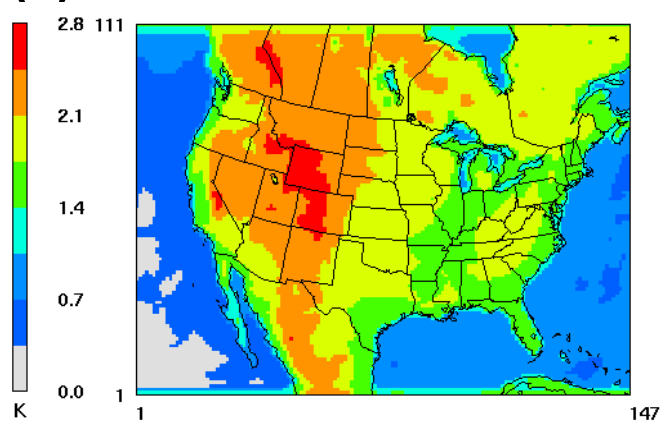

(b)

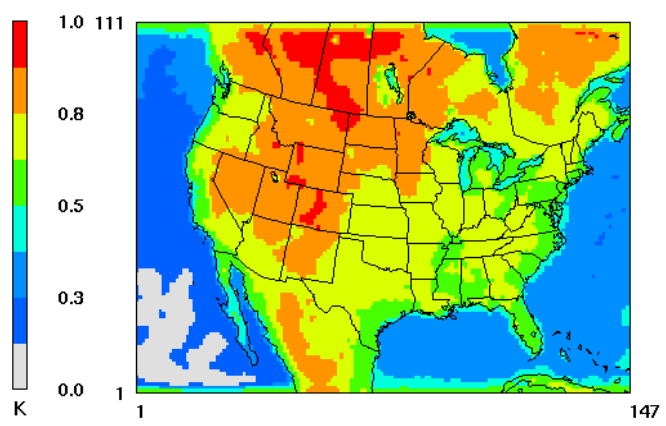

(c)

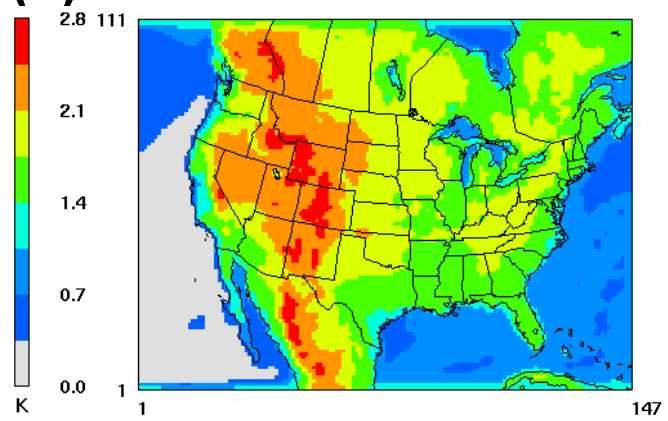

(d)

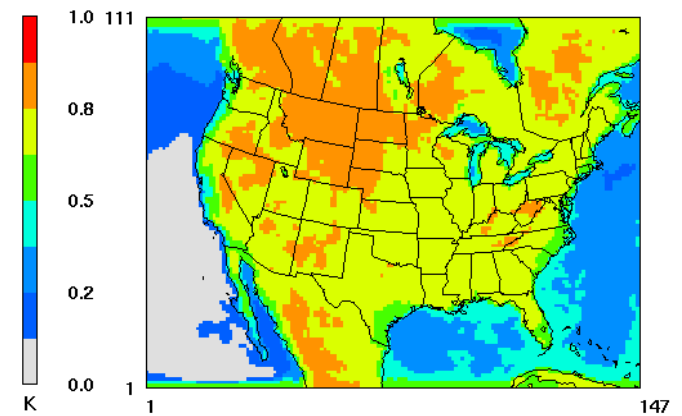

Fig. 2. Spatial distribution of difference (K) in temperature in 2050 for (a) annualized (high-extreme - base case); (b) annualized (base case - low-extreme); (c) summer-averaged (high-extreme - base case); (d) summer-averaged (base case - low-extreme) scenarios.

Table 1. Changes in summer-average and annualized temperatures $(\mathrm{K})$, absolute humidity $(\mathrm{g} / \mathrm{Kg})$ and total VOC (=anthropogenic $+\mathrm{biogenic}$ VOCs) emissions (\%) between 2001 and 2050 base case as well as the three 2050 climate scenarios.

\begin{tabular}{|c|c|c|c|c|c|c|c|c|c|c|c|c|}
\hline & \multicolumn{6}{|c|}{ Summer-average } & \multicolumn{6}{|c|}{ Annualized } \\
\hline & West & Plains & Midwest & Northeast & Southeast & US & West & Plains & Midwest & Northeast & Southeast & US \\
\hline \multicolumn{13}{|l|}{ Temperature (K) } \\
\hline Base case -2001 & 1.8 & 0.6 & 0.2 & 1.8 & 0.9 & 1.0 & 2.4 & 1.1 & 1.0 & 1.8 & 0.4 & 1.3 \\
\hline Base case $-50 \%$ IGSM Climate & 0.5 & 0.0 & -0.5 & -0.2 & 0.3 & 0.1 & 0.0 & -0.1 & -0.1 & 0.1 & 0.4 & 0.0 \\
\hline Low-extreme - Base case & -0.7 & -0.7 & -0.7 & -0.7 & -0.7 & -0.7 & -0.7 & -0.7 & -0.7 & -0.6 & -0.7 & -0.8 \\
\hline High-extreme - Base case & 1.9 & 2.1 & 1.8 & 1.7 & 1.6 & 1.9 & 2.1 & 2.1 & 1.8 & 1.7 & 1.7 & 1.9 \\
\hline \multicolumn{13}{|l|}{ Absolute Humidity (g/Kg) } \\
\hline Base -2001 & 0.7 & 0.6 & 0.9 & 0.8 & 0.5 & 0.7 & 0.5 & 0.5 & 0.6 & 0.7 & 0.7 & 0.6 \\
\hline Base case $-50 \%$ IGSM Climate & -2.0 & -1.0 & -0.2 & -0.3 & -1.0 & -1.0 & -0.8 & -0.5 & -0.1 & -0.2 & -0.4 & -0.5 \\
\hline Low-extreme - Base case & -0.3 & -0.4 & -0.4 & -0.4 & -0.5 & -0.4 & -0.3 & -0.3 & -0.3 & -0.4 & -0.4 & -0.3 \\
\hline High-extreme - Base case & 1.0 & 1.2 & 1.1 & 1.1 & 1.4 & 1.2 & 0.8 & 0.9 & 0.8 & 0.8 & 1.1 & 0.9 \\
\hline \multicolumn{13}{|l|}{ Total VOC Emissions (\%) } \\
\hline Base case -2001 & 16.6 & 3.5 & -16.9 & -3.5 & 5.3 & 2.3 & 11.7 & -9.1 & -26.3 & -19.6 & -16.9 & -11.8 \\
\hline Low-extreme - Base case & -17.0 & -10.3 & 0.4 & 0.1 & -6.9 & -8.3 & -13.9 & -9.1 & -1.4 & -2.4 & -4.9 & -7.6 \\
\hline High-extreme - Base case & 4.1 & 14.9 & 28.5 & 24.2 & 15.6 & 15.4 & 6.3 & 14.0 & 22.0 & 12.9 & 17.1 & 13.2 \\
\hline
\end{tabular}

scenario compared with emissions in 2001, due to planned emission controls. Ammonia $\left(\mathrm{NH}_{3}\right)$ emissions are simulated to increase by about $7 \%$ due to increases in population and related human activities. Total volatile organic compounds (VOC) emissions are predicted to increase by about $2 \%$ for the 2050 base case as a net result of in- creased biogenic VOC emissions and lower anthropogenic VOC emissions for the whole simulation domain (Tagaris et al., 2007; Woo et al., 2008). For the two extreme 2050 scenarios, annualized and summer-average $\mathrm{SO}_{2}, \mathrm{NO}_{\mathrm{x}}$, $\mathrm{NH}_{3}, \mathrm{PM}_{2.5}$ and anthropogenic VOC emissions are predicted to change slightly compared with the 2050 base 
(a)

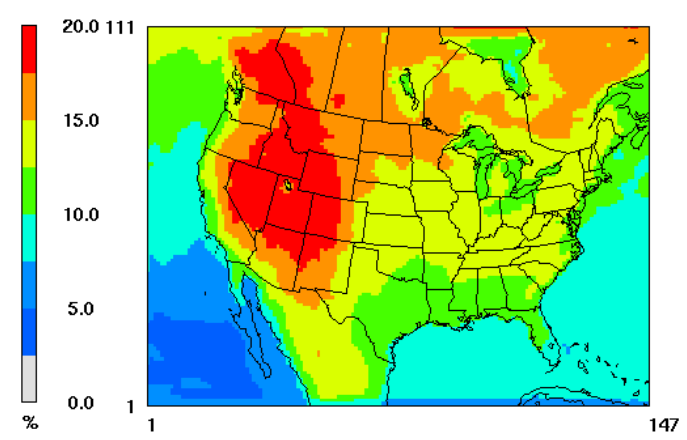

(b)

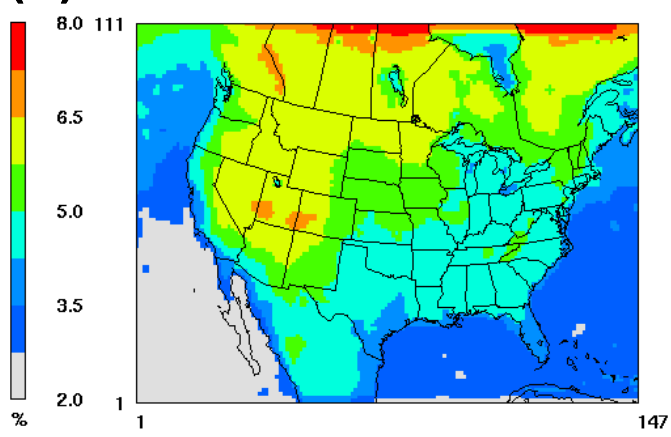

(c)

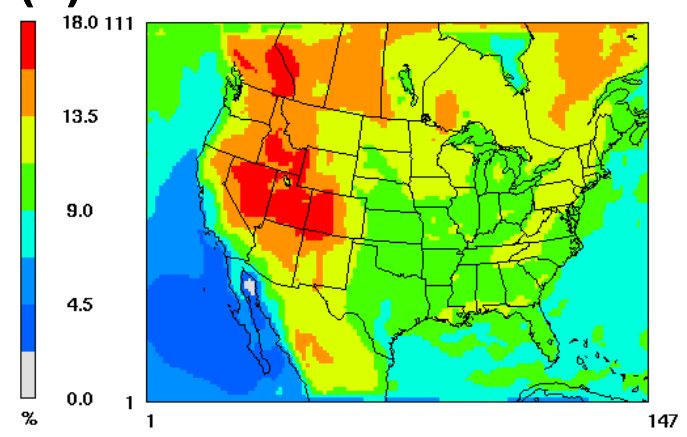

(d)

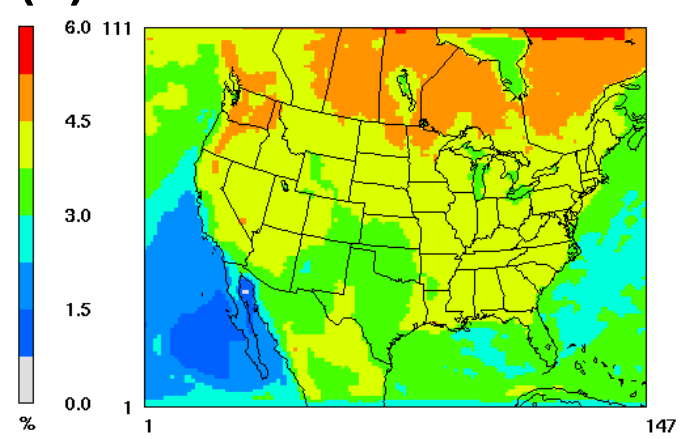

Fig. 3. Spatial distribution of difference (\%) in absolute humidity in 2050 for (a) annualized (high-extreme - base case); (b) annualized (base case - low-extreme); (c) summer-averaged (high-extreme - base case); (d) summer-averaged (base case - low-extreme) scenarios.

scenario (Table S2 http://www.atmos-chem-phys.net/9/865/ 2009/acp-9-865-2009-supplement.pdf). However, predicted total VOC emissions vary significantly as biogenic VOC emissions are much more sensitive to temperature changes than other precursor emissions (Tables 1 and S2). Responses of VOC emissions to the extreme climate scenarios are also found to change spatially. The low-extreme scenario results in an approximately $0-17 \%$ decrease in total VOC (=anthropogenic+biogenic VOC) emissions compared with the 2050 base scenario. For the high-extreme scenario, higher biogenic VOC emissions cause an increase of up to about $22 \%$ in annualized and $29 \%$ in summer-average total VOC emissions compared with the base case in 2050 on a regional basis (Table 1).

\subsection{Summer-average ozone and summertime fourth- highest daily maximum 8 -h average ozone}

Summer-average ozone and daily maximum 8-h ozone concentrations are found to be slightly affected by the extreme climate scenarios in 2050 with typical changes of about 1$2 \mathrm{ppbV}$ between the extreme and base case climate scenarios on a regional basis (Table 2). For the peak ozone levels, summertime (JJA) 4th MDA8h O 3 (4th MDA8h O 3 in the summer of 2050) concentrations for the high-extreme scenario are predicted to increase up to $10 \mathrm{ppbV}$ as compared with the 2050 base case in urban areas of the Northeast, Midwest and Texas in the continental US (Fig. 5). Such differences are attributed to the changes in meteorological fields (e.g., temperature, humidity, etc.) and meteorologyinduce changes in precursor emissions (e.g., increases in biogenic VOC emissions) on the photochemistry of tropospheric ozone. Sensitivity analyses show that peak ground-level ozone levels and ambient temperatures are positively correlated with each other (Baertsch-Ritter et al., 2004; Menut, 2003; Dawson et al., 2007; Aw and Kleeman, 2003). Sillman and Samson (1995) found higher temperatures increase decomposition of peroxyacyl nitrates (PANs) and generate nitrogen dioxides $\left(\mathrm{NO}_{2}\right)$ during the daytime and hence cause higher peak ozone levels. Higher absolute humidity (water vapor concentration) increases hydroxyl radicals $(\mathrm{OH})$, resulting in faster oxidation of VOCs, forming peroxy radicals (e.g., $\mathrm{HO}_{2}, \mathrm{RO}_{2}$ ) which react with nitrogen oxides (NO) to form $\mathrm{NO}_{2}$ (Seinfeld and Pandis, 2006). Even when changes in precursor emissions are not considered, concentrations of summertime (JJA) 4th MDA8h $\mathrm{O}_{3}$ in urban areas are more sensitive to changes in temperatures and absolute humidity than the other areas due to their higher concentrations of PANs, VOC, $\mathrm{CH}_{4}$ and $\mathrm{CO}$, and also expected to find a greater simulated impact from the high-extreme scenario than the base case in 2050. When temperature-induced increases in 

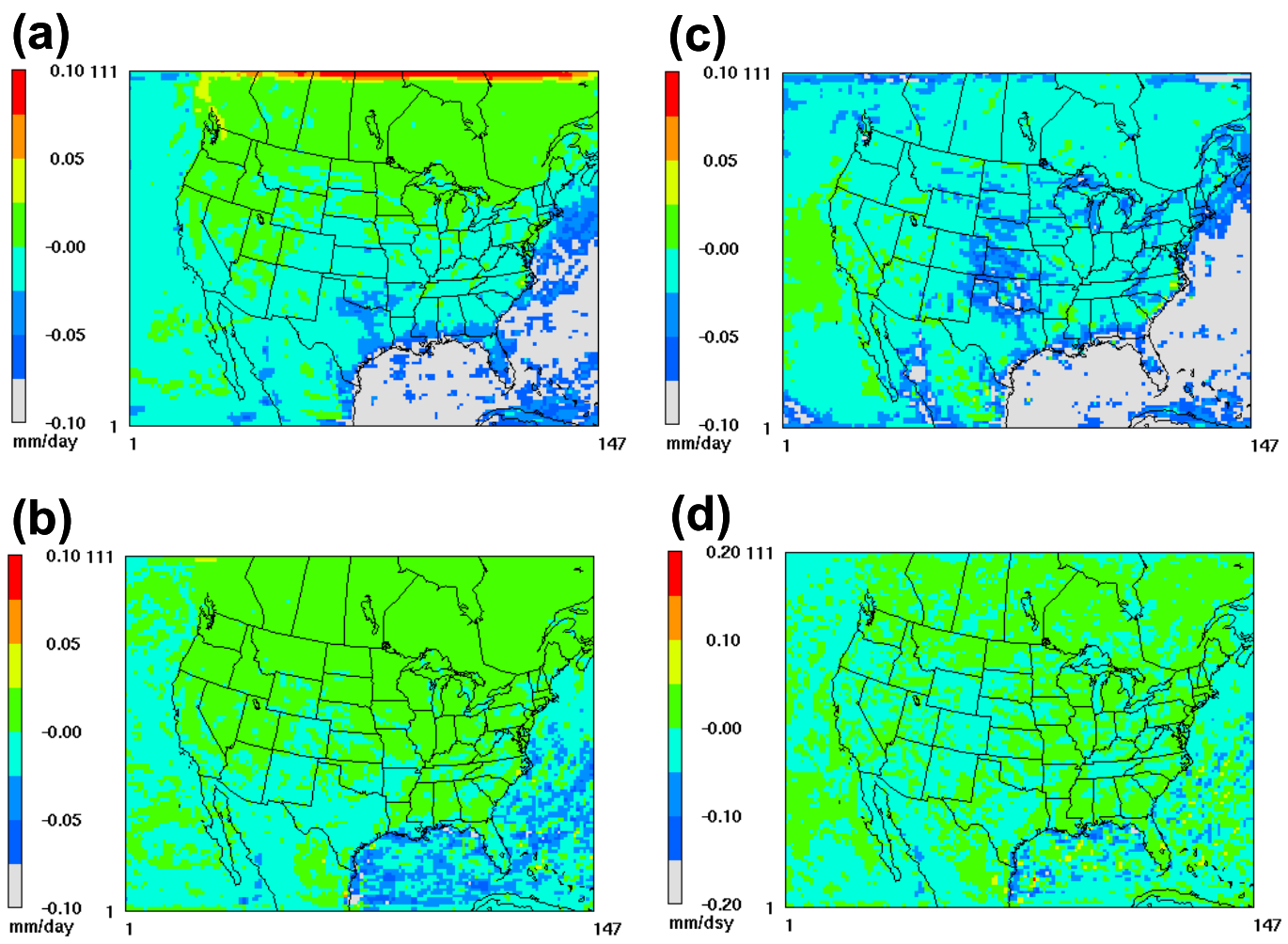

Fig. 4. Spatial distribution of difference (mm/day) in precipitation in 2050 for (a) annualized (high-extreme - base case); (b) annualized (base - low-extreme); (c) Summer-averaged (high-extreme - base case); (d) summer-averaged (base - low-extreme) scenarios.

Table 2. Summer-average ozone and daily maximum 8-h ozone concentrations (in ppbV) for the three climate scenarios for the five regions and US.

\begin{tabular}{lcccccc}
\hline $\mathrm{O}_{3}(\mathrm{ppbV})$ & \multicolumn{3}{c}{ Summer-average ozone } & \multicolumn{3}{c}{ Summer-average daily maximum 8-h ozone } \\
\hline & Low-extreme & Base & High-extreme & Low-extreme & Base & High-extreme \\
\hline West & 41.7 & 41.8 & 41.6 & 50.3 & 50.3 & 50.5 \\
Plains & 40.4 & 40.8 & 41.8 & 48.5 & 49.3 & 50.9 \\
Midwest & 35.4 & 35.8 & 36.7 & 44.9 & 46.0 & 47.2 \\
Northeast & 37.1 & 37.2 & 37.3 & 44.0 & 44.9 & 45.0 \\
Southeast & 42.6 & 42.9 & 43.7 & 52.2 & 52.7 & 54.7 \\
US & 39.9 & 40.3 & 40.9 & 48.5 & 49.2 & 50.3 \\
\hline
\end{tabular}

VOC emissions (especially biogenic VOC emissions) (Table 1 and Fig. 6) are considered, higher ozone levels are found in $\mathrm{NO}_{\mathrm{x}}$-saturated (or VOC-sensitive) urban areas, e.g., Chicago and New York, and the effects of the high-extreme climate scenario are predicted to be more significant. Moreover, for five urban areas in the continental US (i.e., Atlanta, Chicago, Houston, New York and Los Angeles), our previous results show that concentrations of daily maximum 8-h average ozone are predicted to positively respond to VOC emissions on some days for the base case GISS-MM5 simulations in 2050, especially in Chicago and New York, al- though ozone formation is predicted to be more $\mathrm{NO}_{\mathrm{x}}$-limited in 2050 than 2001 due to currently planned emission controls (Liao et al., 2008). On the other hand, increases in VOC emissions are also found to decrease 4th MDA8h O 3 formation in some areas of the West region where ozone formation is VOC-saturated. Furthermore, lower levels of predicted summer precipitation for the high-extreme scenario also lead to more ozone formation and an increase in the differences between the high-extreme and base case scenarios in the polluted urban areas (Fig. 4). The spatial distribution of changes in 4th MDA8h ozone between the 2050 extreme 
(a)

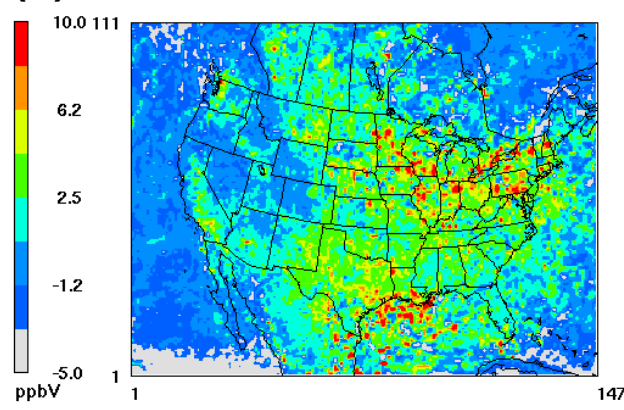

(b)

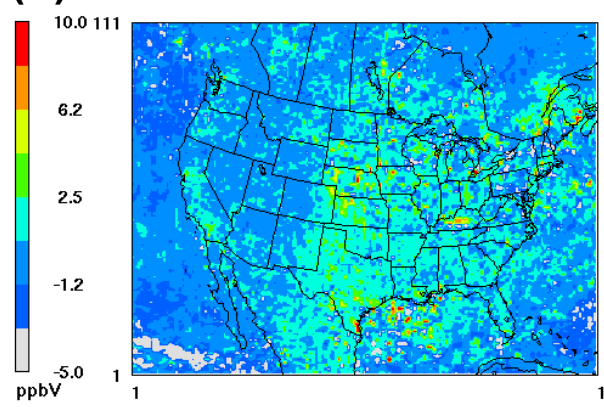

(c)

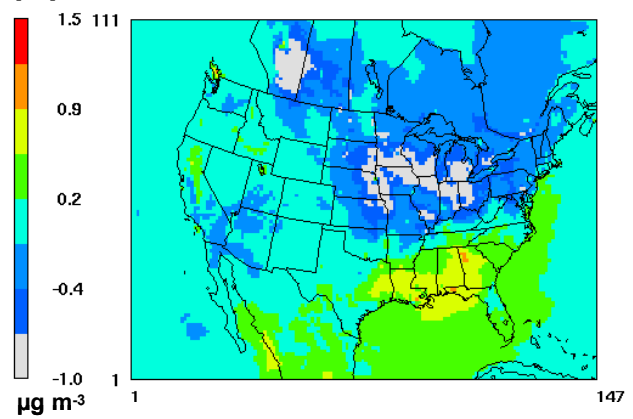

(d)

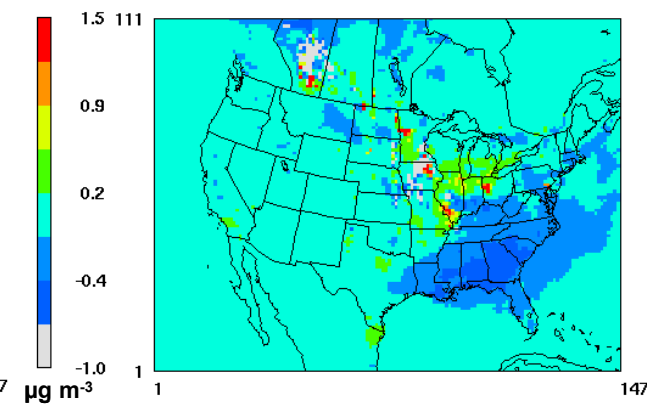

Fig. 5. Spatial distribution of difference in (a) summertime (high-extreme - base scenarios); (b) summertime (base case - low-extreme scenarios) 4th MDA8h O 3 (ppbV); (c) annualized (high-extreme - base case) $\mathrm{PM}_{2.5}$; and (d) annualized (base case - low-extreme scenario) $\mathrm{PM}_{2.5}\left(\mu \mathrm{g} \mathrm{m}^{-3}\right)$.

and base case climate scenarios does not follow that of temperature, absolute humidity and precipitation since groundlevel ozone formation is affected by the combined effects of different climate fields and local precursor emissions as well.

Differences in concentrations of summertime 4th MDA8h $\mathrm{O}_{3}$ are predicted to be approximately $+/-3 \mathrm{ppbV}$ between the base case and low-extreme scenarios (Fig. 5). Concentrations of summertime 4th $\mathrm{MDA}_{8 \mathrm{~h} \mathrm{O}}$ are found to be less sensitive to the low-extreme climate scenario than the highextreme scenario due to smaller differences in meteorological fields between the base case and low-extreme scenario as well as non-linear responses of ozone concentrations to emission changes (Cohan et al., 2005). Tagaris et al. (2007) present an about $20 \%$ decrease in concentrations of summeraverage daily maximum 8 -h ozone and less number of exceedance days of ozone concentration of $85 \mathrm{ppbV}$ in five US cities between 2000-2002 and 2049-2051, mainly due to currently planned emission controls in the future. Here, a maximum change of $10 \mathrm{ppbV}$ in 4th MDA8h O 3 (about oneseventh of the current NAAQS of ozone of $75 \mathrm{ppbV}$ ) is found in 2050 for the high-extreme climate scenario, which may significantly offset the effectiveness of currently planned emission reductions in urban areas with high concentrations of PANs, VOC, $\mathrm{CH}_{4}$ and $\mathrm{CO}$ as well as VOC-sensitive ozone formation regimes.

\subsection{Annualized $\mathrm{PM}_{2.5}$}

$\mathrm{PM}_{2.5}$ levels are influenced by the changes between the climate scenarios in several ways. Higher temperatures favor semi-volatile compounds (e.g., secondary organic aerosols (SOAs) and ammonium nitrate $\left(\mathrm{NH}_{4} \mathrm{NO}_{3}\right)$ ) to remain in the gas phase. On the other hand, increases in temperatures and humidity result in higher emissions of SOA precursors and faster oxidation of $\mathrm{SO}_{2}, \mathrm{NO}_{\mathrm{x}}$ and VOCs, increasing formation of condensable compounds, such as sulfate, nitrate and semi-volatile organic species (SVOCs). Further, changes in precipitation can have a dramatic effect on frequency of washout and fine particle concentrations (Racherla and Adams, 2006). Overall, the net effects of different mechanisms of $\mathrm{PM}_{2.5}$ production and loss result in a -1.0 to $+1.5 \mu \mathrm{g} \mathrm{m}^{-3}$ difference in annualized $\mathrm{PM}_{2.5}$ levels (average of daily $\mathrm{PM}_{2.5}$ levels of January, April, July and October) between the extreme and base scenarios in 2050 (Fig. 5). Larger differences in $\mathrm{PM}_{2.5}$ levels between the extreme and base scenarios are found in the Southeast and Midwest of the continental US due to higher $\mathrm{PM}_{2.5}$ precursor emissions (e.g., anthropogenic $\mathrm{SO}_{2}, \mathrm{NO}_{\mathrm{x}}$, VOC, etc.) in those regions (Table S2). The $1.0 \mu \mathrm{g} \mathrm{m}^{-3}$ decrease in annualized $\mathrm{PM}_{2.5}$ levels in the Midwest for the high-extreme scenario is mainly due to lower sulfate and nitrate in the winter (January) compared with the base case (Table 3 ), while the $0.5 \mu \mathrm{g} \mathrm{m}^{-3}$ 
Table 3. Annualized and seasonal (January, April, July and October) total $\mathrm{PM}_{2.5}$ levels and composition (sulfate, nitrate, secondary organic aerosol (SOA) and primary organic aerosol (POA)) for the three climate scenarios in 2050 for the five regions and US Unit: $\mu \mathrm{g} \mathrm{m}^{-3}$.

\begin{tabular}{|c|c|c|c|c|c|c|c|c|c|c|c|c|c|c|c|c|}
\hline & & \multicolumn{3}{|c|}{ January } & \multicolumn{3}{|c|}{ April } & \multicolumn{3}{|c|}{ July } & \multicolumn{3}{|c|}{ October } & \multicolumn{3}{|c|}{ Annualized } \\
\hline & & $\begin{array}{c}\text { Low- } \\
\text { extreme }\end{array}$ & Base & $\begin{array}{l}\text { High- } \\
\text { extreme }\end{array}$ & $\begin{array}{c}\text { Low- } \\
\text { extreme }\end{array}$ & Base & $\begin{array}{l}\text { High- } \\
\text { extreme }\end{array}$ & $\begin{array}{c}\text { Low- } \\
\text { extreme }\end{array}$ & Base & $\begin{array}{l}\text { High- } \\
\text { extreme }\end{array}$ & $\begin{array}{c}\text { Low- } \\
\text { extreme }\end{array}$ & Base & $\begin{array}{l}\text { High- } \\
\text { extreme }\end{array}$ & $\begin{array}{c}\text { Low- } \\
\text { extreme }\end{array}$ & Base & $\begin{array}{l}\text { High- } \\
\text { extreme }\end{array}$ \\
\hline \multirow{5}{*}{ West } & Sulfate & 0.7 & 0.7 & 0.7 & 0.5 & 0.6 & 0.5 & 0.5 & 0.5 & 0.6 & 0.6 & 0.7 & 0.7 & 0.6 & 0.6 & 0.6 \\
\hline & Nitrate & 0.6 & 0.6 & 0.5 & 0.2 & 0.2 & 0.1 & 0.0 & 0.0 & 0.0 & 0.3 & 0.2 & 0.2 & 0.3 & 0.3 & 0.2 \\
\hline & SOA & 0.6 & 0.6 & 0.7 & 0.7 & 0.7 & 0.8 & 1.0 & 1.0 & 1.1 & 0.9 & 1.0 & 1.1 & 0.8 & 0.8 & 0.9 \\
\hline & POA & 0.9 & 0.9 & 0.9 & 0.7 & 0.7 & 0.7 & 0.7 & 0.7 & 0.7 & 0.9 & 1.0 & 1.0 & 0.8 & 0.8 & 0.8 \\
\hline & Total $\mathrm{PM}_{2.5}$ & 3.2 & 3.1 & 3.1 & 2.4 & 2.4 & 2.5 & 2.4 & 2.4 & 2.6 & 3.3 & 3.3 & 3.4 & 2.8 & 2.8 & 2.9 \\
\hline \multirow{5}{*}{ Plains } & Sulfate & 1.7 & 1.7 & 1.5 & 1.0 & 1.1 & 1.1 & 1.8 & 1.8 & 2.0 & 1.2 & 1.3 & 1.3 & 1.4 & 1.4 & 1.5 \\
\hline & Nitrate & 1.8 & 1.7 & 1.5 & 0.3 & 0.3 & 0.2 & 0.1 & 0.1 & 0.0 & 0.4 & 0.3 & 0.3 & 0.6 & 0.6 & 0.5 \\
\hline & SOA & 0.4 & 0.4 & 0.4 & 0.4 & 0.4 & 0.4 & 0.4 & 0.4 & 0.4 & 0.4 & 0.5 & 0.5 & 0.4 & 0.4 & 0.4 \\
\hline & POA & 0.6 & 0.6 & 0.6 & 0.4 & 0.4 & 0.4 & 0.4 & 0.4 & 0.5 & 0.5 & 0.5 & 0.5 & 0.5 & 0.5 & 0.5 \\
\hline & Total $\mathrm{PM}_{2.5}$ & 7.2 & 7.0 & 6.5 & 3.4 & 3.4 & 3.4 & 4.3 & 4.3 & 4.7 & 4.2 & 4.2 & 4.5 & 4.8 & 4.7 & 4.8 \\
\hline \multirow{5}{*}{ Midwest } & Sulfate & 4.1 & 3.9 & 3.1 & 1.7 & 1.8 & 1.8 & 2.5 & 2.4 & 2.5 & 1.7 & 1.8 & 1.9 & 2.5 & 2.5 & 2.3 \\
\hline & Nitrate & 3.3 & 3.4 & 2.8 & 0.6 & 0.7 & 0.5 & 0.1 & 0.1 & 0.1 & 0.9 & 0.8 & 0.8 & 1.2 & 1.2 & 1.1 \\
\hline & SOA & 0.5 & 0.5 & 0.5 & 0.4 & 0.4 & 0.4 & 0.6 & 0.6 & 0.6 & 0.4 & 0.4 & 0.4 & 0.5 & 0.5 & 0.5 \\
\hline & POA & 0.8 & 0.8 & 0.7 & 0.5 & 0.5 & 0.5 & 0.7 & 0.7 & 0.7 & 0.6 & 0.7 & 0.7 & 0.6 & 0.7 & 0.7 \\
\hline & Total $\mathrm{PM}_{2.5}$ & 14.5 & 13.5 & 12.2 & 5.8 & 5.8 & 5.8 & 6.7 & 6.7 & 6.7 & 6.4 & 6.4 & 6.6 & 8.4 & 8.1 & 7.8 \\
\hline \multirow{5}{*}{ Northeast } & Sulfate & 2.6 & 2.6 & 2.4 & 1.5 & 1.5 & 1.5 & 1.2 & 1.2 & 1.3 & 1.6 & 1.6 & 1.8 & 1.7 & 1.7 & 1.7 \\
\hline & Nitrate & 2.6 & 2.5 & 2.1 & 0.5 & 0.5 & 0.4 & 0.0 & 0.0 & 0.0 & 0.6 & 0.5 & 0.5 & 0.9 & 0.9 & 0.8 \\
\hline & SOA & 0.6 & 0.6 & 0.6 & 0.4 & 0.4 & 0.4 & 0.7 & 0.7 & 0.7 & 0.7 & 0.7 & 0.7 & 0.6 & 0.6 & 0.6 \\
\hline & POA & 0.9 & 0.9 & 0.8 & 0.5 & 0.5 & 0.5 & 0.6 & 0.6 & 0.6 & 0.8 & 0.8 & 0.8 & 0.7 & 0.7 & 0.7 \\
\hline & Total $\mathrm{PM}_{2.5}$ & 9.9 & 9.6 & 8.7 & 4.4 & 4.4 & 4.3 & 3.5 & 3.6 & 3.8 & 5.3 & 5.2 & 5.5 & 5.8 & 5.7 & 5.6 \\
\hline \multirow{5}{*}{ Southeast } & Sulfate & 2.9 & 2.7 & 2.8 & 2.0 & 2.0 & 2.1 & 2.6 & 2.5 & 2.7 & 2.7 & 2.6 & 3.1 & 2.5 & 2.5 & 2.7 \\
\hline & Nitrate & 2.7 & 2.4 & 2.2 & 0.2 & 0.3 & 0.1 & 0.0 & 0.0 & 0.0 & 0.3 & 0.2 & 0.2 & 0.8 & 0.7 & 0.7 \\
\hline & SOA & 1.0 & 0.9 & 1.0 & 0.9 & 0.9 & 0.9 & 0.7 & 0.6 & 0.7 & 1.2 & 1.2 & 1.4 & 0.9 & 0.9 & 1.0 \\
\hline & POA & 1.3 & 1.2 & 1.3 & 0.9 & 0.9 & 0.9 & 1.0 & 0.9 & 1.0 & 1.0 & 1.2 & 1.3 & 1.1 & 1.1 & 1.2 \\
\hline & Total $\mathrm{PM}_{2.5}$ & 10.5 & 10.2 & 9.8 & 5.7 & 5.7 & 5.9 & 5.7 & 5.6 & 5.8 & 6.9 & 7.1 & 7.7 & 7.2 & 7.2 & 7.3 \\
\hline \multirow{5}{*}{ US } & Sulfate & 2.1 & 2.0 & 1.8 & 1.2 & 1.3 & 1.2 & 1.7 & 1.6 & 1.8 & 1.4 & 1.5 & 1.6 & 1.6 & 1.6 & 1.6 \\
\hline & Nitrate & 2.0 & 1.9 & 1.6 & 0.3 & 0.4 & 0.2 & 0.1 & 0.0 & 0.0 & 0.4 & 0.4 & 0.4 & 0.7 & 0.7 & 0.6 \\
\hline & SOA & 0.6 & 0.6 & 0.6 & 0.5 & 0.5 & 0.6 & 0.6 & 0.6 & 0.7 & 0.7 & 0.7 & 0.8 & 0.6 & 0.6 & 0.7 \\
\hline & POA & 0.8 & 0.8 & 0.8 & 0.5 & 0.6 & 0.6 & 0.6 & 0.6 & 0.7 & 0.7 & 0.8 & 0.8 & 0.7 & 0.7 & 0.7 \\
\hline & Total $\mathrm{PM}_{2.5}$ & 8.2 & 7.9 & 7.3 & 4.0 & 4.0 & 4.0 & 4.4 & 4.4 & 4.7 & 4.8 & 4.9 & 5.1 & 5.4 & 5.3 & 5.3 \\
\hline
\end{tabular}

increase in annualized $\mathrm{PM}_{2.5}$ levels in the Southeast for the low-extreme scenario is due to higher nitrate in the winter (January) than the base case (Table 3). SOA is predicted to be influenced by changes in biogenic VOC emissions as well as modifications in the formation rates under the effects of the extreme climate scenarios. In CMAQ version 4.3 , the SOA gas-particle partitioning model is based on the Secondary Organic Aerosol Model (SORGAM) (Schell et al., 2001), which doesn't account for SOA formation from isoprene. Some studies show that isoprene significantly contributes to SOA formation (Claeys et al., 2004), and SOA levels are predicted to be underestimated without including isoprene as a SOA precursor (Zhang et al., 2007; Morris et al., 2006; Pun and Seigneur, 2007). In this study, the changes in $\mathrm{PM}_{2.5}$ levels attributed to the extreme climate scenarios are dominated by sulfate and nitrate $\mathrm{PM}_{2.5}$ in most of the US regions since SOA formation is not fully captured in current regional air quality models (Table 3 ).

Impacts of climate uncertainties on $\mathrm{PM}_{2.5}$ concentrations also show a seasonal trend. Monthly-average $\mathrm{PM}_{2.5}$ concentrations are predicted to be lower in January but slightly higher in July for the high-extreme scenario compared with the 2050 base case (Table 3); this is mainly because tem- peratures change the partitioning of semi-volatile compounds between the gas-phase and particle-phase. Higher temperature and humidity increase sulfate aerosol formation due to faster gas- and aqueous-phase oxidation rates of $\mathrm{SO}_{2}$. Rae et al. (2007) have shown that increases in temperature and changes in oxidant concentrations are simulated to decrease $1 \%$ of Aitken-mode sulfate aerosols but increase of $9.2 \%$ of accumulation-mode sulfate in 2100 assuming climate and emission-induced oxidant levels will follow the IPCC SRES A2 scenario. Total sulfate concentrations are expected to increase by $6.8 \%$ in 2100 compared with 1990 (Rae et al., 2007). Effects of climate on nitrate are more complicated than sulfate due to high vapor pressure for particle-phase ammonium nitrate (Seinfeld and Pandis, 2006). Aw and Kleeman (2003) present that nitrate aerosol may slightly increase with cool temperature $(<290 \mathrm{~K})$ but decrease with hot temperature $(>290 \mathrm{~K})$ as temperature increases. The combined effects of changes in sulfate and nitrates show that the high-extreme climate scenario with associated increases in temperatures in January induces more nitrates and sulfates to be in the gas-phase lowering $\mathrm{PM}_{2.5}$ concentrations. The seasonal trend is reversed in the low-extreme scenario (Table 3). Wise and Comrie (2005) show that, from a long-term 
(a)

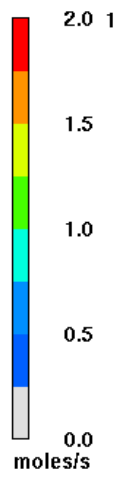

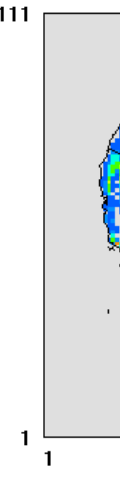

(b)

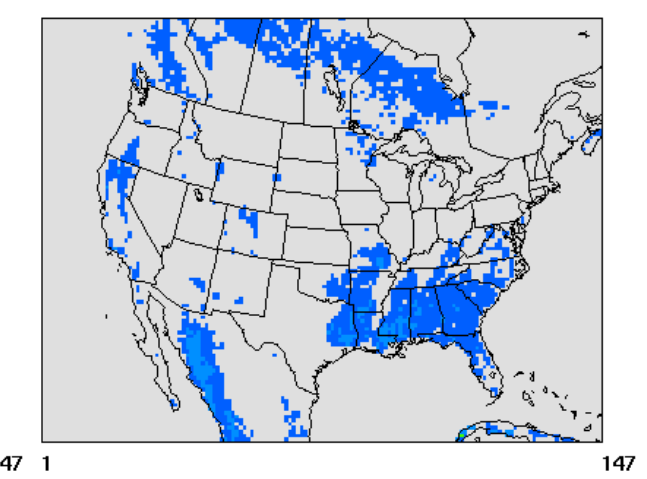

Fig. 6. Spatial distribution of difference (moles/s) in summertime biogenic VOC emissions between (a) high-extreme and base case as well as (b) base case - low-extreme scenarios.

statistical analysis, PM is not as weather-dependent as ozone in the southwestern US since low precipitation is found in the studying region. The results in this study also show that annualized $\mathrm{PM}_{2.5}$ levels are not as sensitive as concentrations of summertime peak ozone with respect to the extreme climate scenarios examined since one of the main removal mechanisms of $\mathrm{PM}_{2.5}$, precipitation scavenging, is found to slightly affect annualized $\mathrm{PM}_{2.5}$ levels between the extreme climate scenarios (Fig. 4). Our previous study shows that annual average $\mathrm{PM}_{2.5}$ levels are predicted to decrease by about $23 \%$ (regionally varies from $-9 \%$ to $-32 \%$ ) in 2050 as a combined effect of future climate change and CAIR emission controls (Tagaris et al., 2007). The results here imply that, on a regional basis, future emission controls will still be effective in decreasing annualized $\mathrm{PM}_{2.5}$ levels with respect to the extreme climate scenarios if precipitation is only slightly affected.

\section{Response of air quality to emission controls under ex- treme climate scenarios}

In addition to simulating how the alternative extreme scenarios impact pollutant levels, we also investigate the responses of ozone and $\mathrm{PM}_{2.5}$ levels to emission controls under the extreme climate scenarios. CMAQ, with the Decoupled Direct Method-3D (DDM-3D) (Dunker et al., 2002; Yang et al., 1997), is used to quantify sensitivities of ozone and $\mathrm{PM}_{2.5}$ to precursor emissions. First-order sensitivities $\left(S_{i, j}\right)$ of pollutant concentration $i\left(C_{i}\right)$ (i.e. ozone and $\left.\mathrm{PM}_{2.5}\right)$ to source emissions $j\left(E_{j}\right)$ (i.e., anthropogenic VOC, anthropogenic $\mathrm{NO}_{\mathrm{x}}$ and total $\mathrm{SO}_{2}$ emissions) are defined as (Yang et al., 1997):

$S_{i, j}=E_{j} \frac{\partial C_{i}}{\partial E_{j}}$
First-order sensitivities represent the locally linear responses of pollutant concentrations to emission changes and have the same units as the concentrations. Sensitivities of summertime 4th MDA8h $\mathrm{O}_{3}$ to anthropogenic $\mathrm{NO}_{\mathrm{x}}$ emissions $\left(S_{4 \text { th } M D A} 8 \mathrm{hO}_{3}, \mathrm{ANO}_{\mathrm{x}}\right)$ are predicted to slightly decrease for the low-extreme scenario but increase for the high-extreme scenario as compared with the base case in 2050. The differences are mainly attributed to the climate effects on biogenic VOC emissions and photochemistry. Biogenic VOC emissions are predicted to increase for the high-extreme scenario, especially in the Southeast region and west coast of the continental US, compared with the base case in the summer of 2050 (Fig. 6). Higher biogenic VOC emissions for the high-extreme attribute to a more $\mathrm{NO}_{\mathrm{x}}$-limit environment for ozone formation and increase $S_{4 \text { th MDA } 8 \mathrm{HO}_{3}, \mathrm{ANO}_{\mathrm{x}}}$. The effects of the extreme climate scenarios on sensitivities of summertime 4th MDA8h $\mathrm{O}_{3}$ to anthropogenic VOC emissions ( $S_{4 \text { th MDA8h O }}$, A VOC $)$ are predicted to be small (Fig. 7). For the responses of $\mathrm{PM}_{2.5}$ to emission changes under the extreme climate scenarios, sensitivities of annualized $\mathrm{PM}_{2.5}$ to $\mathrm{SO}_{2}$ emissions $\left(S_{\mathrm{PM}_{2.5}, \mathrm{SO}_{2}}\right)$ are predicted to slightly increase for the high-extreme scenario on a regional basis, because of higher temperature, humidity, decreased rainfall in some regions, and faster oxidation of precursors as compared with the base scenario. Higher temperatures for the high-extreme scenario favor particulate $\mathrm{NH}_{4} \mathrm{NO}_{3}$ to dissociate to its gas phase precursors and cause slight decreases in sensitivities of annualized $\mathrm{PM}_{2.5}$ concentrations to anthropogenic $\mathrm{NO}_{\mathrm{x}}$ emissions $\left(S_{\mathrm{PM}_{2.5}, \mathrm{ANO}_{\mathrm{x}}}\right)$ (Fig. 7). Overall, on a regional basis, the effectiveness of $\mathrm{NO}_{\mathrm{x}}$ and $\mathrm{SO}_{2}$ emission controls for reducing peak ozone and $\mathrm{PM}_{2.5}$ levels changes little, though climate-driven increases in extreme ozone levels may require additional controls to reach applicable air quality standards.

Annualized monthly maximum daily $\mathrm{PM}_{2.5}$ levels (average of monthly maximum daily $\mathrm{PM}_{2.5}$ for January, April, July and October) and their sensitivities are also examined 

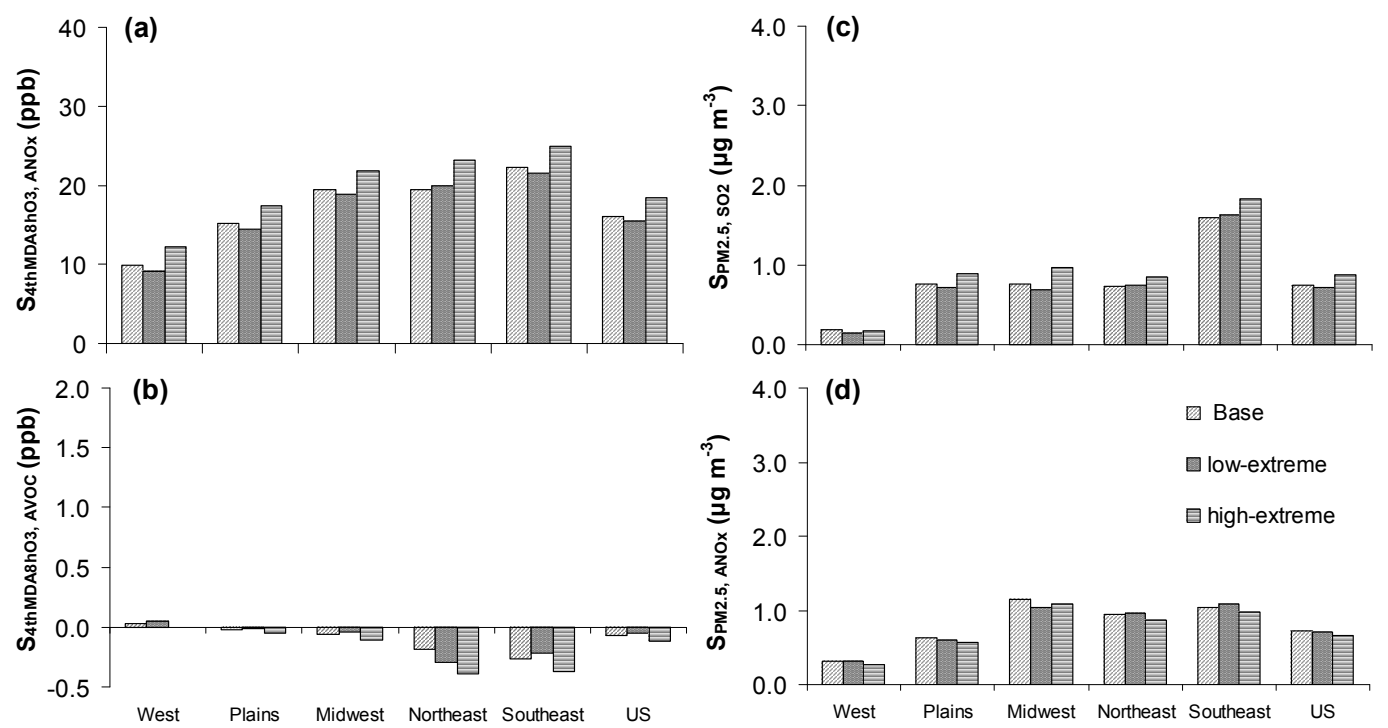

Fig. 7. Sensitivities of 4 th $\mathrm{MDA} 8 \mathrm{~h} \mathrm{O} \mathrm{O}_{3}$ to (a) anthropogenic $\mathrm{NO}_{\mathrm{x}}\left(S_{4 \text { th } \mathrm{MDA} 8 \mathrm{~h} \mathrm{O}}, \mathrm{A} \mathrm{NO}_{\mathrm{x}}\right)$ and (b) anthropogenic VOC $\left(S_{4 \text { th } M D A 8 h} \mathrm{O}_{3}, \mathrm{~A}\right.$ VOC $)$ $(\mathrm{ppbV})$ as well as sensitivities of annualized $\mathrm{PM}_{2.5}$ to (c) anthropogenic $\mathrm{SO}_{2}\left(\mathrm{~S}_{\mathrm{PM}_{2.5}, \mathrm{SO}_{2}}\right)$ and $(\mathbf{d})$ anthropogenic $\mathrm{NO}_{\mathrm{x}}\left(S_{\mathrm{PM}_{2.5}}, \mathrm{ANO}_{\mathrm{x}}\right)$ $\left(\mu \mathrm{g} \mathrm{m}^{-3}\right)$ in 2001 and the 2050 base and extreme scenarios for the five regions and US.

Table 4. Annualized monthly maximum daily $\mathrm{PM}_{2.5}$ levels (average of monthly maximum daily $\mathrm{PM}_{2.5}$ for January, April, July and October) and their sensitivities to $\mathrm{SO}_{2}\left(S_{\mathrm{PM}_{2.5}, \mathrm{SO}_{2}}\right)$, anthropogenic $\mathrm{NO}_{\mathrm{x}}\left(S_{\mathrm{PM}_{2.5}, \mathrm{ANO}_{\mathrm{x}}}\right)$ and VOC $\left(S_{\mathrm{PM}_{2.5}, \mathrm{~A} \text { VOC }}\right)$ for the five US cities for the three climate scenarios in 2050 Unit: $\mu \mathrm{g} \mathrm{m}^{-3}$.

\begin{tabular}{|c|c|c|c|c|}
\hline & & 2050 Low-extreme & 2050 Base & 2050 High-extreme \\
\hline \multirow{4}{*}{ Los Angeles } & $\mathrm{PM}_{2.5}$ & 21.9 & 22.1 & 24.2 \\
\hline & $S_{\mathrm{PM}_{2,5}, \mathrm{SO}_{2}}$ & 0.0 & 0.1 & 0.0 \\
\hline & $S_{\mathrm{PM}_{2.5}, \mathrm{~A} \mathrm{NO}_{\mathrm{x}}}$ & 0.3 & 0.9 & 0.4 \\
\hline & $S_{\mathrm{PM}_{2.5}, \mathrm{~A} \text { VOC }}$ & 0.5 & 0.5 & 0.6 \\
\hline \multirow{4}{*}{ Houston } & $\mathrm{PM}_{2.5}$ & 25.1 & 25.2 & 24.6 \\
\hline & $S_{\mathrm{PM}_{2.5}, \mathrm{SO}_{2}}$ & 3.0 & 3.3 & 3.9 \\
\hline & $S_{\mathrm{PM}_{2.5}, \mathrm{~A} \mathrm{NO}_{\mathrm{x}}}$ & 3.3 & 3.1 & 2.6 \\
\hline & $S_{\mathrm{PM}_{2.5}, \mathrm{~A} \text { VOC }}$ & -0.1 & -0.1 & -0.1 \\
\hline \multirow{4}{*}{ Chicago } & $\mathrm{PM}_{2.5}$ & 36.5 & 36.9 & 38.3 \\
\hline & $S_{\mathrm{PM}_{2,5}, \mathrm{SO}_{2}}$ & 1.7 & 1.9 & 3.3 \\
\hline & $S_{\mathrm{PM}_{2.5}, \mathrm{~A} \mathrm{NO}_{\mathrm{x}}}$ & 5.2 & 4.7 & 7.3 \\
\hline & $S_{\mathrm{PM}_{2.5}, \mathrm{~A} \text { VOC }}$ & 0.7 & 0.7 & 0.4 \\
\hline \multirow{4}{*}{ New York } & $\mathrm{PM}_{2.5}$ & 35.7 & 34.9 & 36.5 \\
\hline & $S_{\mathrm{PM}_{2.5}, \mathrm{SO}_{2}}$ & 1.7 & 1.5 & 1.5 \\
\hline & $S_{\mathrm{PM}_{2.5}, \mathrm{~A} \mathrm{NO}_{\mathrm{x}}}$ & 3.3 & 3.0 & 1.7 \\
\hline & $S_{\mathrm{PM}_{2.5}, \mathrm{~A} \text { VOC }}$ & 0.9 & 0.9 & 1.0 \\
\hline \multirow{4}{*}{ Atlanta } & $\mathrm{PM}_{2.5}$ & 26.5 & 26.4 & 27.1 \\
\hline & $S_{\mathrm{PM}_{2.5}, \mathrm{SO}_{2}}$ & 2.6 & 2.6 & 2.5 \\
\hline & $S_{\mathrm{PM}_{2.5}, \mathrm{~A} \mathrm{NO}_{\mathrm{x}}}$ & 2.0 & 1.9 & 2.8 \\
\hline & $S_{\mathrm{PM}_{2.5}, \text { A VOC }}$ & 0.5 & 0.5 & 0.4 \\
\hline
\end{tabular}


in 2050 for five US urban areas, Atlanta, Chicago, Houston, Los Angeles and New York, where currently have high $\mathrm{PM}_{2.5}$ levels (http://www.epa.gov/oar/oaqps/greenbk/, last access: 15 December 2008). Such areas are particularly susceptible to the climate penalty, especially when tightening of future daily average $\mathrm{PM}_{2.5}$ standards is considered. For the five cities examined, sensitivities of annualized monthly maximum daily $\mathrm{PM}_{2.5}$ to anthropogenic $\mathrm{NO}_{\mathrm{x}}$ emissions are predicted to be affected by the extreme climate scenarios, with changes up to $2.6 \mu \mathrm{g} \mathrm{m}^{-3}$ (Table 4), since ammonium nitrate $\left(\mathrm{NH}_{4} \mathrm{NO}_{3}\right)$ formation is very responsive to changes in meteorology (particularly temperature, Stelson and Seinfeld, 1982). Responses of annualized monthly maximum daily $\mathrm{PM}_{2.5}$ to $\mathrm{SO}_{2}$ emissions are also predicted to be different under the extreme climate scenarios in Chicago due to high $\mathrm{SO}_{2}$ emissions in the Midwest region of the US (Table 4). For four of the five cities examined, Los Angeles being the exception, reductions in $\mathrm{SO}_{2}$ and anthropogenic $\mathrm{NO}_{\mathrm{x}}$ emissions are predicted to continue to be still effective for decreasing annualized monthly peak daily $\mathrm{PM}_{2.5}$ levels under the extreme climate scenarios in 2050. While reductions in anthropogenic $\mathrm{NO}_{\mathrm{x}}$ and VOCs emissions are predicted to be effective for decreasing annualized monthly peak $\mathrm{PM}_{2.5}$ levels in Los Angeles for the three climate scenarios in 2050. Overall, the results for the five cities show that, although the effectiveness of emission controls for decreasing peak $\mathrm{PM}_{2.5}$ levels responds to the extreme climate scenarios, the directions of currently planned emission controls will not be significantly affected.

\section{Conclusions}

Uncertainties associated with simulations of the extreme climate scenarios are found to have a rather moderate effect on predicted emissions of VOC and concentrations of fourthhighest daily maximum 8-h average ozone in year 2050 . Differences in concentrations of fourth-highest daily maximum 8-h average ozone between the extreme climate scenarios and base case are found up to $10 \mathrm{ppbV}$ (about oneseventh of the current ozone standards of $75 \mathrm{ppbV}$ ) in some polluted urban areas due to the combined effects of higher temperature, absolute humidity and VOC emissions, though the change in summer-average ozone is minimal on a regional basis $(\sim 1 \mathrm{ppbV})$. Differences between the extreme and base scenarios in annualized $\mathrm{PM}_{2.5}$ levels are predicted to range between -1.0 and $+1.5 \mu \mathrm{g} \mathrm{m}^{-3}$. For the five US cities examined, sensitivities of annualized monthly maximum daily $\mathrm{PM}_{2.5}$ to anthropogenic $\mathrm{NO}_{\mathrm{x}}$ emissions are predicted to influenced by the extreme climate scenarios since temperature changes significantly affect ammonium nitrate $\left(\mathrm{NH}_{4} \mathrm{NO}_{3}\right)$ formation. Responses of annualized monthly maximum daily $\mathrm{PM}_{2.5}$ to $\mathrm{SO}_{2}$ emissions change most in the Midwest due to locally high emissions. Overall, future annualized $\mathrm{PM}_{2.5}$ is predicted to be less sensitive to the extreme climate scenarios than summertime fourth-highest daily maximum 8-h average ozone since precipitation scavenging is not significantly changed with the extreme climate scenarios where perturbations in temperatures and absolute humidity from the global model are used to drive changes in the regional meteorological modeling. Planned controls for decreasing regional ozone and $\mathrm{PM}_{2.5}$ will continue to be effective in the future under the extreme climate scenarios. However, the impact of climate uncertainties may be substantial in some urban areas and should be included in assessing future regional air quality and emission control requirements.

Acknowledgements. The authors would like to thank US Environmental Protection Agency for providing funding for this project under Science To Achieve Results (STAR) grant No. RD83096001, RD82897602 and RD83107601 and Eastern Tennessee State University. The views expressed in this paper are those of the authors and do not necessarily reflect the views or policies of the EPA. The authors would also like to thank L. Ruby Leung from Pacific Northwest National Laboratory for providing future meteorological data and Loretta Mickley from Harvard University for the GISS simulation used by Leung and Marcus Sarofim for his help in collecting the needed IGSM data.

Edited by: J. Rinne

\section{References}

Aw, J. and Kleeman, M. J.: Evaluating the first-order effect of intraannual temperature variability on urban air pollution, J. Geophys. Res.-Atmos., 108(D12), 4365, doi:10.1029/2002JD002688, 2003.

Babiker, M., Reilly, J., and Ellerman, D.: Japanese nuclear power and the kyoto agreement, J. Jpn. Int. Econ., 14, 169-188, 2000.

Baertsch-Ritter, N., Keller, J., Dommen, J., and Prevot, A. S. H.: Effects of various meteorological conditions and spatial emissionresolutions on the ozone concentration and ROG/ $\mathrm{NO}_{\mathrm{x}}$ limitationin the Milan area (I), Atmos. Chem. Phys., 4, 423-438, 2004 , http://www.atmos-chem-phys.net/4/423/2004/.

Bergin, M. S., Russell, A. G., and Milford, J. B.: Effects of chemical mechanism uncertainties on the reactivity quantification of volatile organic compounds using a three-dimensional air quality model, Environ. Sci. Technol., 32, 694-703, 1998.

Bernard, S. M., Samet, J. M., Grambsch, A., Ebi, K. L., and Romieu, I.: The potential impacts of climate variability and change on air pollution-related health effects in the united states, Environ. Health Persp., 109, 199-209, 2001.

Byun, D. W. and Schere, K. L.: Review of the governing equations, computational algorithms, and other components of the models-3 community multscale air quality (cmaq) modeling system, Appl. Mech. Rev., 59, 51-77, 2006.

Claeys, M., Graham, B., Vas, G., Wang, W., Vermeylen, R., Pashynska, V., Cafmeyer, J., Guyon, P., Andreae, M. O., Artaxo, P., and Maenhaut, W.: Formation of secondary organic aerosols through photooxidation of isoprene, Science, 303, 1173-1176, 2004. 
Cohan, D. S., Hakami, A., Hu, Y. T., and Russell, A. G.: Nonlinear response of ozone to emissions: Source apportionment and sensitivity analysis, Environ. Sci. Technol., 39, 6739-6748, 2005.

Dawson, J. P., Adams, P. J., and Pandis, S. N.: Sensitivity of ozone to summertime climate in the eastern USA: A modeling case study, Atmos. Environ., 41, 1494-1511, 2007.

Dunker, A. M., Yarwood, G., Ortmann, J. P., and Wilson, G. M.: The decoupled direct method for sensitivity analysis in a threedimensional air quality model - implementation, accuracy, and efficiency, Environ. Sci. Technol., 36, 2965-2976, 2002.

Galizia, A. and Kinney, P. L.: Long-term residence in areas of high ozone: Associations with respiratory health in a nationwide sample of nonsmoking young adults, Environ. Health Persp., 107, 675-679, 1999.

Grell, G., Dudhia, J., and Stauffer, D. R.: A description of the fifth generation penn state/ncar mesoscale model (mm5) - ncar tech. Note - ncar/tn-398+str, Natl. Cent for Atmos. Res., Boulder, Colorado, 1994.

Gustafson, W. I. and Leung, L. R.: Regional downscaling for air quality assessment - a reasonable proposition?, B. Am. Meteorol. Soc., 88, 1215-1227, 2007.

Hanna, S. R., Lu, Z. G., Frey, H. C., Wheeler, N., Vukovich, J., Arunachalam, S., Fernau, M., and Hansen, D. A.: Uncertainties in predicted ozone concentrations due to input uncertainties for the uam-v photochemical grid model applied to the july 1995 otag domain, Atmos. Environ., 35, 891-903, 2001.

Hanna, S. R., Russell, A. G., Wilkinson, J. G., Vukovich, J., and Hansen, D. A.: Monte carlo estimation of uncertainties in beis3 emission outputs and their effects on uncertainties in chemical transport model predictions, J. Geophys. Res.-Atmos., 110, D01302, doi:10.1029/2004JD004986, 2005.

Hogrefe, C., Lynn, B., Civerolo, K., Ku, J. Y., Rosenthal, J., Rosenzweig, C., Goldberg, R., Gaffin, S., Knowlton, K., and Kinney, P. L.: Simulating changes in regional air pollution over the eastern united states due to changes in global and regional climate and emissions, J. Geophys. Res.-Atmos., 109, D22301. doi:10.1029/2004JD004690, 2004.

Holian, G., Sokolov, A., and Prinn, R.: Uncertainty in atmospheric $\mathrm{CO}_{2}$ predictions from a parametric uncertainty analysis of a global ocean carbon cycle model, report no. 80, Joint Program on the Science and Policy of Global Change, MIT, Boston, MA, 2001.

Houyoux, M.: Cair emissions inventory overview, US Environmental Protection Agency, 2004.

IPCC: Climate change 2007: The physical science basis, Cambridge University Press, Cambridge, UK, 2007.

Johnson, P. R. S. and Graham, J. J.: Fine particulate matter national ambient air quality standards: Public health impact on populations in the northeastern united states, Environ. Health Persp., 113, 1140-1147, 2005.

Leung, L. R. and Gustafson, W. I.: Potential regional climate change and implications to us air quality, Geophys. Res. Lett., 32, L16711, doi:10.1029/2005GL022911, 2005.

Levy, J. I., Carrothers, T. J., Tuomisto, J. T., Hammitt, J. K., and Evans, J. S.: Assessing the public health benefits of reduced ozone concentrations, Environ. Health Persp., 109, 1215-1226, 2001.

Liao, K. J., Tagaris, E., Manomaiphiboon, k., Woo, J. H., He, S., Amar, P., and Russell, A. G.: Current and future linked responses of ozone and $\mathrm{PM}_{2.5}$ to emission controls, Environ. Sci. Technol., 42, 4670-4675, 2008.

Melillo, J. M., McGuire, A. D., Kicklighter, D. W., Moore, B., Vorosmarty, C. J., and Schloss, A. L.: Global climate-change and terrestrial net primary production, Nature, 363, 234-240, 1993.

Menut, L.: Adjoint modeling for atmospheric pollution process sensitivity at regional scale, J. Geophys. Res.-Atmos., 108(D17), 8562, doi:10.1029/2002JD002549, 2003.

Mickley, L. J., Jacob, D. J., Field, B. D., and Rind, D.: Effects of future climate change on regional air pollution episodes in the united states, Geophys. Res. Lett., 31, L24103, doi:10.1029/2004GL021216, 2004.

Morris, R. E., Koo, B., Guenther, A., Yarwood, G., McNally, D., Tesche, T. W., Tonnesen, G., Boylan, J., and Brewer, P.: Model sensitivity evaluation for organic carbon using two multipollutant air quality models that simulate regional haze in the southeastern united states, Atmos. Environ., 40, 4960-4972, 2006.

Murazaki, K. and Hess, P.: How does climate change contribute to surface ozone change over the united states?, J. Geophys. Res.Atmos., 111, D05301, doi:10.1029/2005JD005873, 2006.

Nakićenović, N.: Special report on emissions scenarios, Cambridge University Press, Cambridge, UK, 2000.

Nenes, A., Pandis, S. N., and Pilinis, C.: Isorropia: A new thermodynamic equilibrium model for multiphase multicomponent inorganic aerosols, Aquat. Geochem., 4, 123-152, 1998.

Prinn, R., Jacoby, H., Sokolov, A., Wang, C., Xiao, X., Yang, Z., Eckhaus, R., Stone, P., Ellerman, D., Melillo, J., Fitzmaurice, J., Kicklighter, D., Holian, G., and Liu, Y.: Integrated global system model for climate policy assessment: Feedbacks and sensitivity studies, Clim. Change, 41, 469-546, 1999.

Pun, B. K. and Seigneur, C.: Investigative modeling of new pathways for secondary organic aerosol formation, Atmos. Chem. Phys., 7, 2199-2216, 2007,

http://www.atmos-chem-phys.net/7/2199/2007/.

Racherla, P. N. and Adams, P. J.: Sensitivity of global tropospheric ozone and fine particulate matter concentrations to climate change, J. Geophys. Res.-Atmos., 111, D24103, doi:10.1029/2005JD006939, 2006.

Rae, J. G. L., Johnson, C. E., Bellouin, N., Boucher, O., Haywood, J. M., and Jones, A.: Sensitivity of global sulphate aerosol production to changes in oxidant concentrations and climate, J. Geophys. Res.-Atmos., 112, D10312, doi:10.1029/2006JD007826, 2007.

Reilly, J., Prinn, R., Harnisch, J., Fitzmaurice, J., Jacoby, H., Kicklighter, D., Melillo, J., Stone, P., Sokolov, A., and Wang, C.: Multi-gas assessment of the kyoto protocol, Nature, 401, 549$555,1999$.

Rind, D., Lerner, J., Shah, K., and Suozzo, R.: Use of on-line tracers as a diagnostic tool in general circulation model development 2. Transport between the troposphere and stratosphere, J. Geophys. Res.-Atmos., 104, 9151-9167, 1999.

Russell, A. and Dennis, R.: Narsto critical review of photochemical models and modeling, Atmos. Environ., 34, 2283-2324, 2000.

Sanderson, M. G., Jones, C. D., Collins, W. J., Johnson, C. E., and Derwent, R. G.: Effect of climate change on isoprene emissions and surface ozone levels, Geophys. Res. Lett., 30(18), 1936, doi:10.1029/2003GL017642, 2003.

Schell, B., Ackermann, I. J., Hass, H., Binkowski, F. S., and Ebel, 
A.: Modeling the formation of secondary organic aerosol within a comprehensive air quality model system, J. Geophys. Res.Atmos., 106, 28275-28293, 2001.

Seaman, N. L.: Meteorological modeling for air-quality assessments, Atmos. Environ., 34, 2231-2259, 2000.

Seinfeld, J. H. and Pandis, S. N.: Atmospheric chemistry and physics: From air pollution to climate change, 2nd ed., John Wiley \& Sons, Inc., New York, 2006.

Sillman, S. and Samson, F. J.: Impact of temperature on oxidant photochemistry in urban, polluted rural and remote environments, J. Geophys. Res.-Atmos., 100, 11497-11508, 1995.

Sokolov, A. P. and Stone, P. H.: A flexible climate model for use in integrated assessments, Clim. Dynam., 14, 291-303, 1998.

Stelson, A. W. and Seinfeld, J. H.: Thermodynamic prediction of the water activity, $\mathrm{NH}_{4} \mathrm{NO}_{3}$ dissociation-constant, density and refractive-index for the $\mathrm{NH}_{4} \mathrm{NO}_{3}-\left(\mathrm{NH}_{4}\right)_{2} \mathrm{SO}_{4}-\mathrm{H}_{2} \mathrm{O}$ system at 25-degrees-C, Atmos. Environ., 16, 2507-2514, 1982.

Strader, R., Lurmann, F., and Pandis, S. N.: Evaluation of secondary organic aerosol formation in winter, Atmos. Environ., 33, 48494863, 1999.

Tagaris, E., Manomaiphiboon, K., Liao, K. J., Leung, L. R., Woo, J. H., He, S., Amar, P., and Russell, A. G.: Impacts of global climate change and emissions on regional ozone and fine particulate matter concentrations overthe us, J. Geophys. Res.-Atmos., 112, D14312, doi:10.1029/2006JD008262, 2007.

Tian, H., Melillo, J. M., Kicklighter, D. W., McGuire, A. D., and Helfrich, J.: The sensitivity of terrestrial carbon storage to historical climate variability and atmospheric $\mathrm{CO}_{2}$ in the united states, Tellus Series B-Chemical and Physical Meteorology, 51, 414452, 1999.
Wang, C., Prinn, R. G., and Sokolov, A.: A global interactive chemistry and climate model: Formulation and testing, J. Geophys. Res.-Atmos., 103, 3399-3417, 1998.

Webster, M., Forest, C., Reilly, J., Babiker, M., Kicklighter, D., Mayer, M., Prinn, R., Sarofim, M., Sokolov, A., Stone, P., and Wang, C.: Uncertainty analysis of climate change and policy response, Clim. Change, 61, 295-320, 2003.

Wise, E. K. and Comrie, A. C.: Meteorologically adjusted urban air quality trends in the southwestern united states, Atmos. Environ., 39, 2969-2980, 2005.

Woo, J. H., He, S. P., Amar, P., Tagaris, E., Manomaiphiboon, K., Liao, K. J., and Russell, A. G.: Development of mid-century anthropogenic emissions inventory in support of regional air quality modeling under influence of climate change, J. Air Waste Mag. Asso., 58, 1483-1494, 2008.

Wunderli, S. and Gehrig, R.: Influence of temperature on formation and stability of surface pan and ozone - a 2-year field-study in switzerland, Atmos. Environ., Part a-General Topics, 25, 1599_ 1608, 1991.

Yang, Y. J., Wilkinson, J. G., and Russell, A. G.: Fast, direct sensitivity analysis of multidimensional photochemical models, Environ. Sci. Technol., 31, 2859-2868, 1997.

Zhang, Y., Huang, J. P., Henze, D. K., and Seinfeld, J. H.: Role of isoprene in secondary organic aerosol formation on a regional scale, J. Geophys. Res.-Atmos., 112, D20207, doi:10.1029/2007JD008675, 2007. 